\section{Influence of Hepatitis G Virus Infection on Liver Disease}

\author{
I.D. Diamantis ${ }^{1 *}$, E. Kouroumalis ${ }^{2}$, \\ M. Koulentaki ${ }^{2}$, E. Fasler-Kan ${ }^{1}$, \\ P.A. Schmid ${ }^{3}$, H.H. Hirsch ${ }^{4}$, H. Bühler ${ }^{3}$, \\ K. Gyr ${ }^{1}$, M. Battegay ${ }^{1}$
}

The influence of hepatitis $\mathrm{G}$ virus (HGV) infection on disease activity in hepatitis $C$ related and unrelated liver disease was investigated in 254 individuals using an EIA polymerase chain reaction assay for HGV. One hundred patients had chronic hepatitis $\mathrm{C}, 26$ primary biliary cirrhosis, and 30 alcoholic liver cirrhosis. In addition, 51 hepatitis B surface antigen (HBsAg)-positive and 47 anti-hepatitis $\mathrm{C}$ virus ( $\mathrm{HCV}$ )-positive blood donors were screened. Hepatitis $G$ virus was detected in $18 \%$ of patients with chronic hepatitis C, $13 \%$ of patients with alcoholic liver cirrhosis, $11 \%$ of patients with primary biliary cirrhosis, $10 \%$ of anti-HCV-positive blood donors, and $2 \%$ of HBsAg-positive blood donors. Virus load and alanine aminotransferase (ALT) levels did not differ significantly in patients with HCV alone versus patients coinfected with $\mathrm{HCV}$ and HGV. However, mild liver fibrosis correlated with HGV coinfection. Hepatitis $G$ virus did not influence ALT levels or liver damage in liver disease unrelated to viral infection.

Hepatitis G virus (HGV) (1) belongs to the Flaviviridae family and has a genomic organization similar to that of the hepatitis C virus (HCV) (2). Hepatitis $\mathrm{G}$ virus has been detected in patients with liver diseases such as chronic and acute hepatitis $(1,3-5)$ and in patients with risk factors of

\footnotetext{
${ }^{1}$ Outpatient Department of Internal Medicine and Department of Research, Petersgraben 4, University Hospital Basel, 4031 Basel, Switzerland.

2 Department of Gastroenterology, University Hospital Heraklion, Crete, Greece.

${ }^{3}$ Department of Internal Medicine, Waid Hospital, Zürich, Switzerland.

${ }^{4}$ Institute for Medical Microbiology of the University of Basel, Basel, Switzerland.
}

parenteral exposure, e.g. multiple transfusions (6) and intravenous drug use (7). Hepatitis $G$ virus was also detected in patients with no evidence of liver disease and without known risk factors, such as volunteer blood donors. Recent reports suggest that coinfection of $\mathrm{HCV}$-infected patients with $\mathrm{HGV}$ does not influence the outcome of $\mathrm{HCV}$ related hepatitis or the response to interferon therapy $(8,9)$. The aims of this study were (i) to study the prevalence of $\mathrm{HGV}$ infection in patients with chronic liver disease and in blood donors found positive for hepatitis B surface antigen ( $\mathrm{HBsAg}$ ) or anti-HCV; (ii) to examine whether HGV had an influence on HCV replication; and (iii) to analyze whether HGV/HCV coinfection influences the degree of liver disease.

Patients and Methods. Data and sera from 254 patients were analyzed. Of these patients, 100 had histologically proven chronic hepatitis $\mathrm{C}$ (Waidspital Zürich, Switzerland), 26 had primary biliary cirrhosis, and 30 had alcoholic liver cirrhosis (University Hospital of Heraklion, Greece). Samples from 47 anti-HCV-positive and $51 \mathrm{HBsAg}$-positive blood donors were also obtained from the University Hospital of Heraklion, Greece.

Total nucleic acids were extracted from serum according to published methods (10) and subjected to reverse transcriptase reaction. For the detection of $\mathrm{HGV}$ sequences, two sets of primers were used. One set derives from the NS5a region (5'CTC TTT GTG GTA GCC GAG AGA T-3', position 6904 and 5'-CGA ATG AGT CAG AGG ACG GGG TAT-3' position 7059) and gives rise to a $156 \mathrm{bp}$ polymerase chain reaction (PCR) fragment, and the other derives from the 5'-non coding region (5'-NCR) (5'-CGG CCA AAA GGT GGT GGA TG-3' position 100, and 5'CGA CGA GCC TGA CGT CGG G-3' position 285 ) and gives rise to a $186 \mathrm{bp}$ PCR fragment. An Expand PCR system (Boehringer, Mannheim, Germany) was used, with 45 cycles of $1 \mathrm{~min}$ at $94^{\circ} \mathrm{C}, 1 \mathrm{~min}$ and $25 \mathrm{sec}$ at $55^{\circ} \mathrm{C}$, and $1 \mathrm{~min}$ at $72^{\circ} \mathrm{C}$. To confirm the specificity of amplified products, and EIA PCR employing an EIA PCR labelling and detection system was used (Boehringer Mannheim). The specific probes for the hybridization were biotinylated at the 5'-end. The probe for the NS5a region was 5'-biotin-GTT ACT GAG AGCAGC TCA GAT-3' position NS5a 152172 and for the 5'-NCR region 5'-biotin-GGT AGC CACTAT AGG TGG G-3'. As positive control $\mathrm{HGV}$, ribonucleic acid (RNA) transcripts were used, a generous gift from Genelabs Technologies, USA. Values higher than the cutoff level (3 
Table 1: Characteristics of 100 patients with chronic hepatitis $\mathrm{C}$.

\begin{tabular}{|c|c|c|c|c|}
\hline Characteristics & $\begin{array}{l}\text { Patients coinfected } \\
\text { with HGV/HCV } \\
(n=18)\end{array}$ & $\begin{array}{l}\text { Patients infected } \\
\text { with HCV only } \\
(n=82)\end{array}$ & $\begin{array}{l}\text { Total } \\
(n=100)\end{array}$ & $P$ value \\
\hline \multicolumn{5}{|l|}{ Risk factor; no. (\%) } \\
\hline Intravenous drug use & $11(32)$ & $23(68)$ & $34 \quad(34)$ & \\
\hline Transfusion & $3(25)$ & $9(75)$ & $12(12)$ & \\
\hline None & $4(8)$ & $50 \quad(92)$ & $54 \quad(54)$ & \\
\hline Mean age in years $( \pm S D)$ & $37(27-68)$ & $46(26-83)$ & $44(26-83)$ & $0.05^{a}$ \\
\hline Mean ALT level in U/ml ( \pm SD) & $133 \pm 78$ & $108 \pm 103$ & & $0.09^{a}$ \\
\hline Mean HCV viral load in Eq/ml & $264049 \pm 293635$ & $301096 \pm 616829$ & & $0.3^{\mathrm{a}}$ \\
\hline \multicolumn{5}{|l|}{ Genotype; no. (\%) } \\
\hline $3 a$ & $6(33)$ & $12(15)$ & 18 & \\
\hline $1 b$ & $5(28)$ & $29(35)$ & 34 & \\
\hline $1 a$ & $2(11)$ & $9(11)$ & 11 & \\
\hline Other/mixed infection & $5(28)$ & $32(39)$ & 37 & \\
\hline
\end{tabular}

times the mean value of 3 negative controls) in the EIA PCR assay were defined as positive.

The HCV viral load was measured using the Amplicor system (Roche, Switzerland). Antibodies against $\mathrm{HCV}$ and $\mathrm{HBsAg}$ were detected by immunoassays. Histological examination was performed using standard criteria, with fibrosis assessed semiquantitatively (11). The Innolipa strip assay (Innogenetics, Belgium) was used for detection of HCV and analysis of genotype. For the statistical analysis, the Yates corrected chi-square method and the Wilcoxon test were applied.

Results and Discussion. Of 100 patients with histologically proven chronic hepatitis C, 34 had used intravenous drugs, 12 had a history of transfusions, and the remaining 54 had no known risk factors (Table 1). Altogether, 18 of $100(18 \%)$ HCV-infected patients were coinfected with HGV. The highest prevalence was found in intravenous drug users $(32 \%)$. Patients infected with HCV alone were older $(p=0.05)$. Thirty-three percent of coinfected patients but only $15 \%$ of patients with HCV infection alone had HCV genotype $3 \mathrm{a}$, whereas $28 \%$ of coinfected and $35 \%$ of patients infected with $\mathrm{HCV}$ alone had genotype 1b. Genotype 1a was found in an equal proportion of both groups $(11 \%)$. Other genotypes, including infections with a mixture of genotypes, were found in $28 \%$ of coinfected patients and in $39 \%$ of patients with HCV infection alone. Ninety-four of the 100 patients had elevated ALT levels. Although $\mathrm{HGV} / \mathrm{HCV}$ coinfected patients had slightly higher ALT levels, the difference was not significant ( $p=0.09$, Wilcoxon test, Table 1 and Fig- ure 1A). Virus load was slightly higher in patients with HCV infection alone, but the difference did not reach significance ( $\mathrm{p}=0.3$, Wilcoxon test, Table 1 and Figure 1B). In both groups ALT and virus load values were distributed over a broad range. Of the 18 patients coinfected with $\mathrm{HGV}$ and HCV, $16(90 \%)$ had histologically proven mild liver fibrosis; only two patients showed a severe fibrosis. Both patients with severe liver fibrosis and $\mathrm{HGV} / \mathrm{HCV}$ coinfection had a mixture of $\mathrm{HCV}$ genotypes. All six patients with genotype $3 a$, all five with genotype $1 \mathrm{~b}$, and both with genotype $1 \mathrm{a}$ had mild fibrosis. Forty-seven of $82(58 \%)$ patients with $\mathrm{HCV}$ infection alone had mild fibrosis, and $35(42 \%)$ had severe fibrosis. The difference regarding fibrosis in $\mathrm{HGV} / \mathrm{HCV}$ versus $\mathrm{HCV}$-infected patients was statistically significant $(\mathrm{p}=0.02$, Yates corrected chi-square test).

Twenty-six patients with primary biliary cirrhosis (median age 63 years, range 36-78 years) were analyzed. Only four individuals had elevated ALT levels. Histologically, eight patients had grade IV liver disease, four had grade III, seven grade II, and the remaining four grade I. Three of the $26 \mathrm{pa}-$ tients were infected with HGV $(11.5 \%)$. However, ALT was elevated in only one HGV-infected patient without severe disease. Thirty patients with alcoholic liver disease were examined, two of whom had elevated ALT levels but were infected with HCV. Hepatitis $\mathrm{G}$ virus was detected in four patients $(13 \%)$, all of whom had normal ALT levels. The histological degree of liver injury was not different in $\mathrm{HGV}$ positive or negative patients.

Fifty-one HBsAg-positive and 47 anti-HCV-positive blood donors were examined. Four of the 
ALT LEVELS

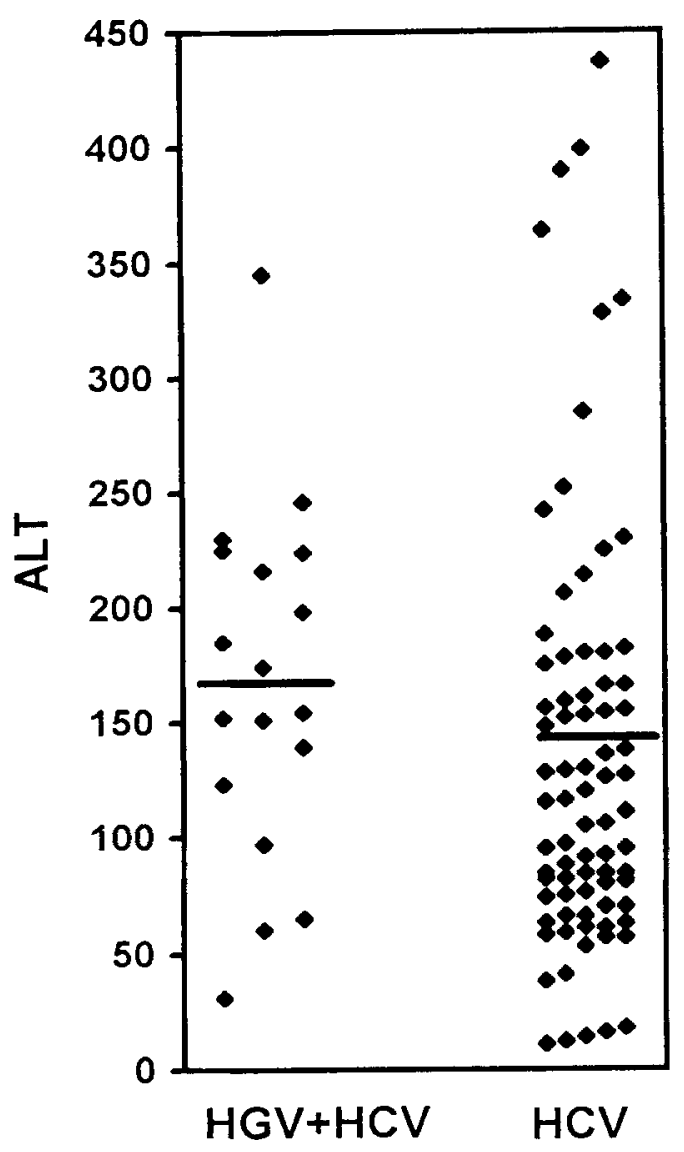

A
VIRAL LOAD

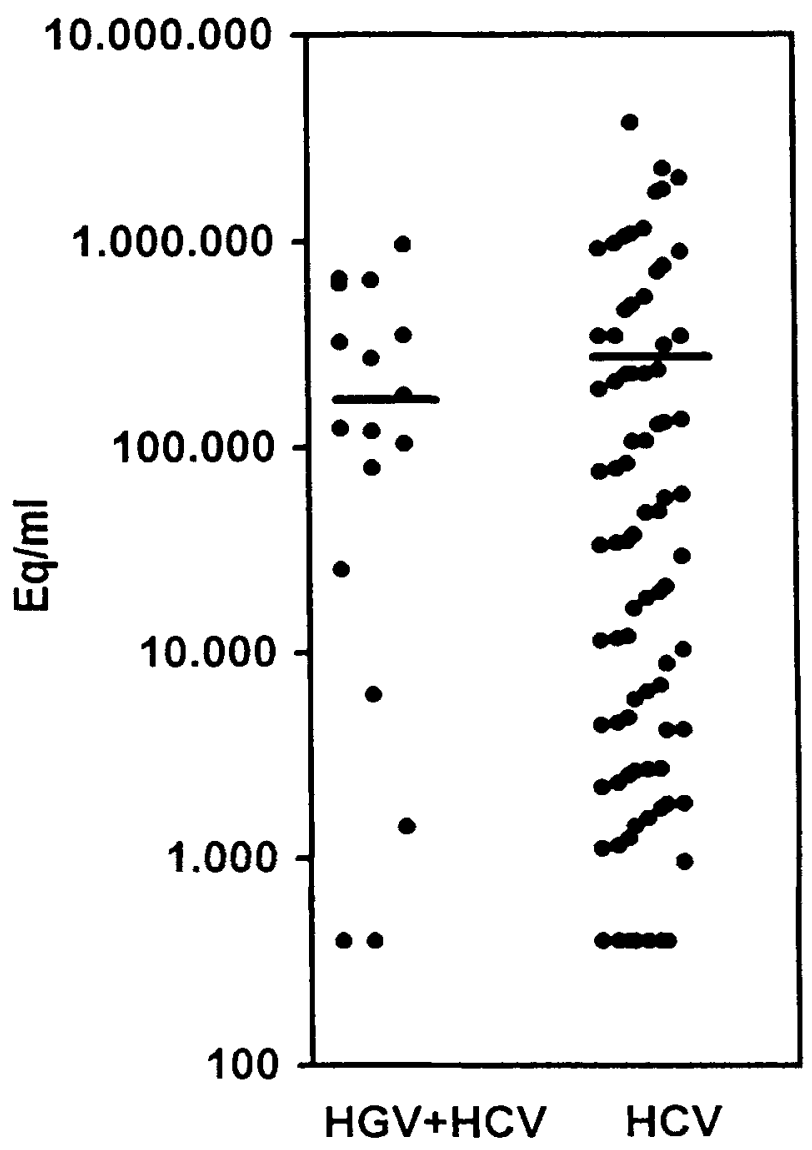

B

Figure 1: Alanine aminotransferase levels and HCV viral load values in individual patients with chronic hepatitis $\mathrm{C}$ coinfected with HGV or infected with HCV alone. Figure $1 \mathrm{~A}$ shows the alanine aminotransferase levels and $1 \mathrm{~B}$ the viral load values. The mean value is indicated by a horizontal line. Alanine aminotransferase is given in $\mathrm{U} / \mathrm{I}$ and the viral load in equivalent viral copies per milliliter.

HBsAg-positive blood donors and two of the anti-HCV-positive donors had elevated ALT levels. Only one of 51 (2\%) HBsAg-positive blood donors was HGV positive, with a normal ALT level. In the group of anti-HCV-positive donors, five were $\mathrm{HGV}$ positive $(10 \%)$, all of whom had normal ALT levels.

In this study we found that (i) $\mathrm{HGV}$ is prevalent in patients with chronic hepatitis $\mathrm{C}$ and different risk factors as well as in patients with other liver diseases; (ii) viremia did not differ significantly in $\mathrm{HGV} / \mathrm{HCV}$-coinfected versus $\mathrm{HCV}$-infected patients; and (iii) HGV/HCV coinfection was significantly associated with mild fibrosis.
The prevalence of $\mathrm{HGV}$ is higher in HCV-infected patients with risk factors, such as intravenous drug use and transfusions $(7,12)$. Interestingly, patients infected with HGV were younger than patients infected with HCV alone. Possibly, hepatitis $\mathrm{G}$, in contrast to hepatitis $\mathrm{C}$, is a self-limited viral infection that is cleared from the serum after a number of years, resulting in infection by $\mathrm{HCV}$ alone after years or decades. This hypothesis is supported by our previous finding that drug users who started intravenous heroin use before 1980 had a lower prevalence of HGV than those who started after 1980 (7). Alternatively, this observation may be explained by the notion that HGV was introduced only recently in these populations. Hepatitis $\mathrm{G}$ virus and HCV share the paren- 
teral mode of transmission, but the high prevalence found in patients with alcoholic liver cirrhosis, patients with primary biliary cirrhosis, and other low-risk groups investigated in our study suggests that other modes of transmission probably occur.

Virus load and ALT levels were slightly but not significantly different in $\mathrm{HCV}$-infected versus $\mathrm{HGV} / \mathrm{HCV}$-coinfected patients. Possibly, as both viruses belong to the Flaviviridae family and have a high degree of sequence homology, interferences may occur at many stages, e.g., at the replication level or during the production of viral proteins. In this study we found that HGV/HCV coinfection may lead to a rather mild course of liver disease. Similarly, Tanaka et al. (8) observed a tendency for less severe liver fibrosis in $\mathrm{HGV} / \mathrm{HCV}$-coinfected patients. Our observation, that all patients with $\mathrm{HCV}$ genotypes $3 \mathrm{a}$ and $1 \mathrm{~b}$ coinfected with $\mathrm{HGV}$ had only mild fibrosis, indicates that this difference is probably not due to genotypes, since $1 \mathrm{~b}$ is usually correlated with severe disease (13).

One limitation of this study may be that the two groups of patients with chronic hepatitis, the one coinfected with $\mathrm{HGV} / \mathrm{HCV}$ and the other with $\mathrm{HCV}$ alone, were different regarding age, mode of acquisition, and possibly other factors. This may have influenced our results regarding severity of fibrosis. In particular, the older age in the group of patients with $\mathrm{HCV}$ infection alone may have negatively influenced the degree of liver fibrosis.

Neither ALT levels nor the severity of liver pathology was influenced in alcoholic liver disease or primary biliary cirrhosis, suggesting that $\mathrm{HGV}$ infection plays rather a secondary role in the development of these diseases, with no etiologic link. The higher prevalence of HGV infection among these patients as compared to the normal population may indicate that a liver with pathology enables the persistence of $\mathrm{HGV}$ infection.

In conclusion, the data presented in this study support the hypothesis that HGV infection does not worsen the outcome of HCV infection and may even have a favorable effect.

\section{Acknowledgment}

The authors thank Genelabs Technologies, Redwood City, CA, USA, for providing the $\mathrm{HGV}$ positive control, Alana Althage for critical reading of the manuscript, and Michèle Girard for excellent secretarial assistance.

This study was supported by a grant from the Swiss National Science Foundation (32-43'413.95) and the Kanton of BaselStadt.

\section{References}

1. Linnen J, Wages J, Zhang-Keck ZY, Kyrk EF, Krawczynski KZ, Alter $\mathrm{H}$, Koonin E, Gallagher M, Alter M, Hadziyannis $S$, Karayiannis P, Fung $K$, Nakatsuji $Y$, Shih JW, Young L, Piatak M, Hoover C, Fernandez J, Chen S, Zou JC, Morris T, Hyams KC, Ismay S, Lifson JD, Hess G, Foung SK, Thomas H, Bradley D, Margolis H, Kim JP: Molecular cloning and disease association of hepatitis $G$ virus: a transfusion-transmissible agent. Science 1996, 271: 505-509.

2. Simons LN, Leary TP, Dawson GJ, Pilot-Matias TJ, Muerhoff AS, Schlauder GG, Desai SM, Mushahwar IK: Isolation of novel virus-like sequences associated with human hepatitis. Nature Medicine 1995, 1: 564-569.

3. Yoshiba M, Okamoto H, Mishiro S: Detection of the GBV$C$ hepatitis virus genome in serum from patients with fulminant hepatitis of unknown aetiology. Lancet 1995, 346: 1131-1132.

4. Nakatsuji Y, Shih JW-K, Tanaka E, Kiyosawa K, Wages $\mathrm{J}$, Kim JP, Alter HJ: Prevalence and disease association of hepatitis $G$ virus infection in Japan. Journal of Viral Hepatitis 1996, 3: 307-316.

5. Alter MJ, Gallagher M, Morris TT, Moyer, LA, Meeks EL, Krawczynski K, Kim JP, Margolis HS: Acute non A-E hepatitis in the United States and the role of hepatitis $G$ virus infection. New England Journal of Medicine 1997, 336: 741-746.

6. Alter HJ, Nakatsuji Y, Melpolder J, Wages J, Wesley R, Shih JW, Kim JP: The incidence of transfusion associated hepatitis $\mathrm{G}$ virus infection and its relation to liver disease. New England Journal of Medicine 1997, 336: 747-754.

7. Diamantis ID, Bassetti S, Erb P, Ladewig D, Gyr K, Battegay $M$ : High prevalence and coinfection rate of hepatitis $G$ and $C$ infections in i.v. drug users. Journal of Hepatology 1997, 26: 794-797.

8. Tanaka E, Alter HJ, Nakatsuji Y, Shih JW, Kim JP, Matsumoto $A$, Kobayashi M, Kiyosawa K: Effect of hepatitis $G$ virus infection on chronic hepatitis $C$. Annals of Internal Medicine 1996, 125: 740-743.

9. Berg T, Dirla U, Naumann U, Heuft HG, Kuether S, Lobeck $H$, Schreier E, Hopf U: Responsiveness to interferon alpha treatment in patients with chronic hepatitis $C$ coinfected with hepatitis $G$ virus. Journal of Hepatology 1996, 25: 763-768.

10. Chomczynski P, Sacchi N: Single-step method of RNA isolation by acid guanidinium thiocyanate-phenol-chloroform extraction. Annals of Biochemistry 1987, 162: 156-159.

11. Knodel RG, Ishak KG, Black WC, Chen TS, Craig R, Kaplowitz N, Kiernan TW: Formulation and application of a numerical scoring system for assessing histological activity in asymptomatic chronic active hepatitis. Hepatology 1981, 1: 431-435.

12. Schreier E, Höhne M, Künkel U, Berg, T, Hopf U: Hepatitis GBV-C sequences in patients infected with HCV contaminated immunoglobulin and among i.v. drug users in Germany. Journal of Hepatology 1996, 25: 385-389.

13. Pawlotsky JM, Tsakiris L, Roudot-Thoraval F, Pellet $C$, Stuyver L, Duval J, Dhumeaux D: Relationship between hepatitis $C$ virus genotypes and sources of infection in patients with chronic hepatitis C. Journal of Infectious Diseases 1995, 171: 1607-1610. 